\title{
肝硬変を伴った非外傷性脳出血.
}

$\begin{array}{llllllll}\text { 斉 } & \text { 藤 } & \text { 厚 } & \text { 志 } & \text { 成 島 } & \text { 浄 松 村 明 } \\ \text { 目 } & \text { 黒 } & \text { 琴 } & \text { 生 能 勢 忠 } \text { 男* }^{*} & & \end{array}$

\section{Treatment of Nontraumatic Intracranial Hemorrhage in Liver Cirrhosis Patients : Clinical Features and Outcomes in Nine Patients}

by

\section{Atsushi Saito, M.D., Kiyoshi Narushima, M.D., Akira Matsumura, M.D., Kotoo Meguro, M.D., and Tadao Nose, M.D.*}

from

Department of Neurosurgery, Tsukuba Medical Center Hospital, and

*Department of Neurosurgery, Institute of Clinical Medicine, University of Tsukuba

We have analyzed the clinical features and outcomes of nontraumatic intracranial hemorrhage in 9 patients with liver cirrhosis. The results have revealed that the hepatitis $C$ virus was the most frequent cause of their liver cirrhosis. Further, the major site of intracranial hemorrhage was found to be the subcortical region of the cerebrum.

Bleeding tendency in liver cirrhosis patients is usually due to thrombocytopenia and to reduced coagulation factors, and in all 9 patients of this study, thrombocytopenia was seen. Two of these patients also showed a prolonged prothrombin time.

Five of these 9 patients underwent surgical treatment, and though bleeding complications occurred after two craniotomies, three burr-hole operations were accomplished successfully. For these patients, therapy consisted of minimaly invasive surgery with sufficient supplements of thrombocytes and coagulation factors.

Three chronic-phase patients died of hepatic failure or a ruptured esophageal varix. When treating intracranial hemorrhage in liver cirrhosis patients, neurosurgeons should collaborate with specialists of bleeding management and the liver.

(Received March 17, 1995 ; accepted May 9, 1995)

Key words : intracranial hemorrhage, liver cirrhosis, bleeding tendency, thrombocytopenia, coagulopathy

Jpn J Neurosurg (Tokyo) $4:$ 472-477, 1995

\section{緒 言}

非外傷性脳出血の原因抢よび増悪因子としては，高血 圧, 脳動脈瘤, 脳動静脈奇形 $(\mathrm{AVM})$, 脳腫瘍, 血液疾 患, 抗凝固薬などがよく知られている2)8. 肝硬変患者は, 一般に非外傷性脳出血を起こしにくいといわれてい る1)616). しかし，いったん発症した後は，急性期に扔け
る脳出血の治療は, 主にその出血傾向のために困難であ る3) 5) 12) 15). また, 慢性期には肝硬変自体に㨁接起因す る死亡も多く，予後は不良のことが多い. 肝硬変を伴っ た非外傷性脳出血についての臨床的検討は, 文献上非常 に少な(4)771011). 今回われわれは, 1986〜1993 年までに 当院で経験した肝硬変を伴った非外傷性脳出血 9 症例に ついて,脳神経外科医の視点から検討したので報告する。

筑波メディカルセンター病院脳神経外科〔連絡先：斉藤厚志, テ 371 前橋市昭和町 3-39-22 群馬大学医学部第一病理学教室〕 Address reprint requests to : Atsushi Saito, M.D., Department of Pathology, Gunma University School of Medicine, 3-39 -22 Showa-machi, Maebashi, Gunma 371, Japan

*筑波大学臨床医学系脳神経外科 


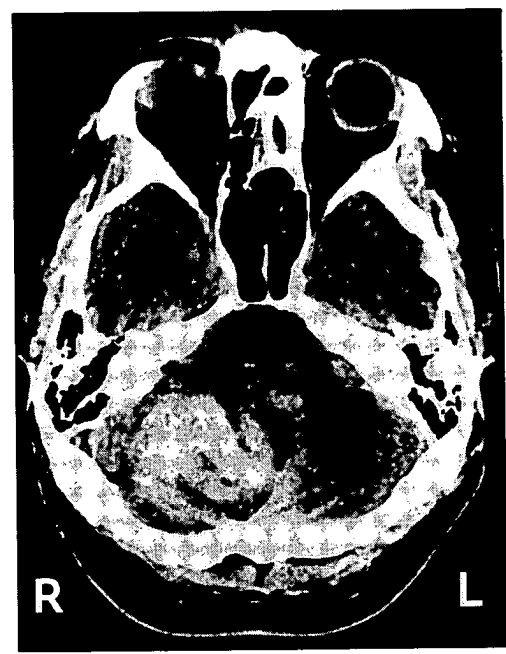

Fig. 1 Case 1

A plain computed tomographic (CT) scan shows a large irregular shaped cerebellar hemorrhage.

\section{対象亡方法}

1986〜1993 年までに筑波メディカルセンター病院に 入院した患者の中で, 肝硬変を伴った非外傷性脳出血 9 症例を対象とした。まず，代表的症例 2 例を呈示した。 次に, すべての症例の年齢, 性別, 肝硬変を含む既往歴, 脳出血の部位, 血液凝固障害の状態, 肝機能デー夕, 脳 出血の手術と補充療法の有無, 経過について検討したの で，その結果を示した。

\section{代表例の呈示}

\section{【症例 1】}

患 者：48 歳, 男性

主 訴：頭痛・嘔吐, 意識障害

既往歴: 高血圧と肝硬変 (輸血後 C 型肝炎) のため他院 通院中.

現病歴：1993 年 10 月 12 日午前中に頭痛・嘔吐で発 症. 別の近医を経て搬入後, 急速に意識低下し, 昏睡状 態となった。

頭部 CT：右側小脳半球に直径 $4 \mathrm{~cm} く ら い の$ 不整形の 出血あり (Fig. 1)。

凝固系データ：血小板数 6.2 万 $/ \mathrm{mm}^{3}$, プロトロンビン 時間 $(\mathrm{PT})$ 延長 $(-)$, 活性化部分トロンボプラスチン 時間 (APTT) 延長 $(-)$.

肝機能データ: glutamic-oxaloacetic transaminase (GOT) $134 \mathrm{IU} / l$ (正常值 35 以下), glutamic-pyruvic transaminase (GPT) $103 \mathrm{IU} / l$ (正常値 40 以下), ビリ ルビン $2.5 \mathrm{mg} / \mathrm{d} l$ (正常値 1.1 以下).

手 術: 緊急後頭下開頭血腪除去·外減圧術. 小脳内血

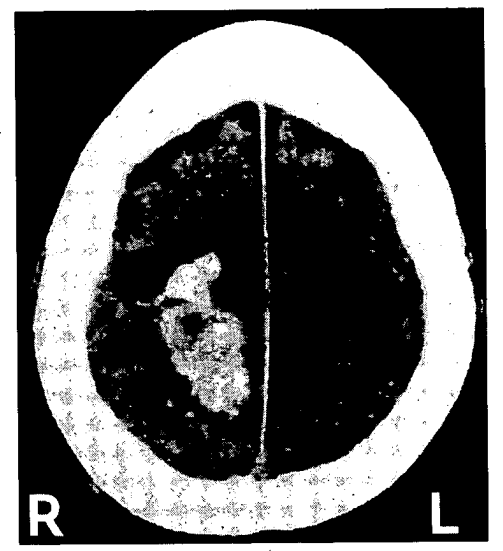

Fig. 2 Case 2

A plain CT scan shows subcortical hemorrhage in the right frontoparietal lobes.

腫除去部位では，脳実質全体からにじみ出るような大量 の出血があり，止血はきわめて困難であった，術中出血 は $5,600 \mathrm{~m} l$ に達し，院内採血による生血 $3,000 \mathrm{~m} l$ およ び fresh frozen plasma (FFP) 5 U の輪血を要し，かろ うじて止血できた。しかし，術直後の CT で再出血があ り, 再手術時には生血 $800 \mathrm{~m} l$ とちょうど到着した濃厚血 小板 $20 \mathrm{U}$ を輸血して, やっと止血できた.

病理所見：手術標本には異常血管・脳腫瘍などはな かった。

術後経過：脳出血の急性期は脱したが，水頭症になっ た。肝硬変による腹水のため,脳室一腹腔短絡術は行えず, 脳室一心房短絡術を要した。 意識障害が遷延し, 最終的に は肝腎症候群となり，11月18日に死亡した。

【症例 2】

患 者：54 歳, 男性

主 訴: 左片麻痺

既往歴：肝硬変（アルコール性）のため他院通院中.

現病歴：1991 年 8 月 13 日昼食後, 左片麻痺に気づき, 別の近医を経て搬入された。意識清明.

頭部 CT : 右側前頭・頭頂葉に少し不整形な皮質下出血 あり (Fig. 2)。

凝固系データ: 血小板数 11.5 万 $/ \mathrm{mm}^{3}, \mathrm{PT}$ 延長 $(+)$, APTT 延長 (-), フィブリノーゲン $134 \mathrm{mg} / \mathrm{d} l$ (正常 值 150 400).

肝機能データ : GOT $81 \mathrm{IU} / l$, GPT $65 \mathrm{IU} / l$, ビリルビ ン $2.8 \mathrm{mg} / \mathrm{d} l$, alkaline phosphatase (ALP) $278 \mathrm{IU} / l$ (正 常値 50 220), $\gamma$-glutamyl transpeptidase ( $\gamma$-GTP) $136 \mathrm{IU} / l$ (正常值 55 以下), indocyanine green (ICG) 血 中停滞率 50\% (正常値 10 以下).

脳血管造影所見：右側頭葉に小さい AVM があった 
Table 1 List of liver cirrhosis patients and the site of the nontraumatic intracranial hemorrhage

\begin{tabular}{|c|c|c|c|c|c|}
\hline $\begin{array}{l}\text { Cáse } \\
\text { No. }\end{array}$ & $\begin{array}{c}\text { Age } \\
\text { (years) }\end{array}$ & Sex & $\begin{array}{c}\text { Cause of } \\
\text { liver cirrhosis }\end{array}$ & $\begin{array}{l}\text { Other medical } \\
\text { history }\end{array}$ & $\begin{array}{c}\text { Site of the } \\
\text { intracranial hemorrhage }\end{array}$ \\
\hline 1 & 48 & $\mathrm{M}$ & $\mathrm{HCV}$ & $\mathrm{HT}$ & right cerebellum \\
\hline 2 & 54 & $\mathrm{M}$ & alcoholic hepatitis & & right subcortex \\
\hline 3 & 59 & M & unknown & $\mathrm{HT}$ & left subcortex \\
\hline 4 & 58 & $\mathrm{M}$ & $\mathrm{HCV}$ & & right subcortex \\
\hline 5 & 68 & $\mathrm{~F}$ & Schistosomiasis japonica & & right subcortex \\
\hline 6 & 78 & $\mathrm{M}$ & unknown & & left $\mathrm{ICH}+\mathrm{ASDH}$ \\
\hline 7 & 51 & M & $\mathrm{HCV}$ & HT, DM, dialysis & left putamen \\
\hline 8 & 69 & M & unknown & $\mathrm{HT}$ & left putamen \\
\hline 9 & 79 & $\mathrm{~F}$ & $\mathrm{HCV}$ & & SAH (distal ACA aneurysm) \\
\hline
\end{tabular}

$\mathrm{HCV}$ : hepatitis $\mathrm{C}$ virus $\mathrm{DM}$ : diabetes mellitus $\mathrm{HT}:$ hypertension $\mathrm{SAH}:$ subarachnoid hemorrhage ICH : intracerebral hemorrhage ACA : anterior cerebral artery ASDH : acute subdural hematoma

Table 2 Bleeding and liver dysfunction data of the liver cirrhosis patients with a nontraumatic intracranial hemorrhage

\begin{tabular}{ccccccc}
\hline $\begin{array}{c}\text { Case } \\
\text { No. }\end{array}$ & $\begin{array}{c}\text { Platelet count } \\
\left(\times 10^{4} / \mathrm{mm}^{3}\right)\end{array}$ & $\begin{array}{c}\text { Prolonged } \\
\text { PT }\end{array}$ & $\begin{array}{c}\text { Prolonged } \\
\text { APTT }\end{array}$ & $\begin{array}{c}\text { GOT } \\
(\mathrm{IU} / l)\end{array}$ & $\begin{array}{c}\text { GPT } \\
(\mathrm{IU} / l)\end{array}$ & $\begin{array}{c}\text { Bilirubin } \\
(\mathrm{mg} / \mathrm{d} l)\end{array}$ \\
\hline 1 & 6.2 & $(-)$ & $(-)$ & 134 & 103 & 2.5 \\
2 & 11.5 & $(+)$ & $(-)$ & 81 & 65 & 2.8 \\
3 & 4.4 & & & 82 & 64 & 1.7 \\
4 & 6.9 & $(+)$ & $(-)$ & 123 & 70 & 1.9 \\
5 & 6.0 & & & 32 & 11 & \\
6 & 11.5 & $(-)$ & $(-)$ & 34 & 14 & 1.1 \\
7 & 10.4 & $(-)$ & $(-)$ & 25 & 30 & 0.5 \\
8 & 8.9 & & & 30 & 20 & 0.8 \\
9 & 11.9 & $(-)$ & $(-)$ & 122 & 66 & 0.8 \\
\hline PT : prothrombin time & APTT : activated & partial thromboplastin time \\
GOT : glutamic-oxaloacetic transaminase & GPT : glutamic-pyruvic trans- \\
aminase & \multicolumn{5}{l}{}
\end{tabular}

が，出血部位には異常は認められなかった。

手 術：CT上，血腫の増大がみられたため，FFP 10 $\mathrm{U}$ 投与後， 8 月 16 日穿頭エコーガイド血腫ドレナージ 術を施行した。術後再出血はなかった。

術後経過：リハビリテーション後, 近医に独歩転院し た.

\section{結. 果}

肝硬変を伴った非外傷性脳出血 9 症例をまとめて, 得 られた特徴は以下の通りである(Table 1〜3).

1. 年齢は $48 \sim 79$ 歳で, 平均 62.7 歳であり, 9 例中 7 例 $(77.8 \%)$ が男性であった。

2. 肝硬変の原因が明らかな 6 例中 4 例 $(66.7 \%)$ が C型肝炎ウイルス $(\mathrm{HCV})$ であり，残りの 2 例はアル コール性肝硬変および日本住血吸虫による肝硬変であっ た。

3. 非外傷性脳出血の部位は，大脳皮質下出血が 4 例
$(44.4 \%)$ で最も多く，次いで被款出血 2 例で，残りは小 脳出血 1 例, 脳内出血 + 急性硬膜下血腫が 1 例, くも膜 下出血（前大脳動脈遠位部動脈确）1例であった。

4. 術前の血小板数は, 全例 $(100 \%)$ で正常值下限よ りも低下していた．PT・APTT を術前に測定できた 6 例中，PT 延長を 2 例 $(33.3 \%)$ に認めた。

5. 肝機能デー夕の中でどの施設でも初診時緊急検査 として術前に検討可能と思われる GOT, GPT, ビリル ビシをみてみると，いずれも正常範囲内であった症例が 9 例中 4 例 $(44.4 \%)$ もあった。

6. 開頭血腫除去術が 2 例に行われたが，そのうち 1 例は血小板・凝固因子の補充療法を併用したにもかかわ らず，止血が困難で術後再出血を生じた。もう1例は補 充療法を併用しないで止血できたが，術後に巨大な創部 皮下血腫を生じた。これに対して, 穿頭血腫ドレナージ 術は 3 例行われ, いずれも補充療法を併用し, 術後経過 は良好であった。

7. 長期経過では, 肝不全・食道静脈瘤破裂などの肝 
Table 3 Treatment provided and clinical course of the liver cirrhosis patients with a nontraumatic intracranial hemorrhage

\begin{tabular}{|c|c|c|c|c|}
\hline $\begin{array}{l}\text { Case } \\
\text { No. }\end{array}$ & $\begin{array}{c}\text { Surgery } \\
\text { (contraindication) }\end{array}$ & $\begin{array}{c}\text { Transfusion of } \\
\text { platelets and/or FFP }\end{array}$ & Clinical course & GOS \\
\hline 1 & craniotomy & $(+)$ & re-bleeding, hepatic failure & $\mathrm{D}$ \\
\hline 2 & burr-hole operation & $(+)$ & & MD \\
\hline 3 & burr-hole operation & $\cdot(+)$ & brain stem hemorrhage & PVS \\
\hline 4 & burr-hole operation & $(+)$ & & $\mathrm{MD}$ \\
\hline 5 & (cardiac failure) & & hepatic failure, pneumonia & $\mathrm{D}$ \\
\hline 6 & craniotomy & $(-)$ & $\begin{array}{l}\text { postoperative subcutaneous } \\
\text { hemorrhage, respiratory failure }\end{array}$ & $\mathrm{D}$ \\
\hline 7 & (dialysis) & & & $\mathrm{SD}$ \\
\hline 8 & (small hematoma) & & ruptured esophageal varix & $\mathrm{D}$ \\
\hline 9 & (advanced age) & & aneurysm rerupture & $\mathrm{D}$ \\
\hline
\end{tabular}

FFP : fresh frozen plasma MD : moderate disability GOS: Glasgow Outcome Scale PVS : persistent vegetative state $\mathrm{D}:$ death $\mathrm{SD}$ : severe disability

硬変に直接起因する死亡例が 3 例 $(33.3 \%)$ あった。こ れに，呼吸不全と脳動脈瘤再破裂による死亡各 1 例を加 えると，合計 5 例（55.6\%）が死亡した。また，皮質下 出血に対する穿頭血腫ドレナージ術の 20 日後に,血圧上 昇などの誘因のない脳幹出血を起こして，植物状態に なった症例が 1 例あった。ささらに，脳出血後独歩不能と なったが，以前からの腎不全に対する透析療法の継続を 目的として転院した 1 例もあった。結局，独歩退院は， 皮質下出血に対する穿頭血腫ドレナージ術後の 2 例のみ (22.2\%) であった。

\section{考 察}

肝硬変を伴った非外傷性脳出血の管理の要点は以下の ようにまとめられる。

《術前》1. 肝硬変扔よび出血傾向の合併に気づくこ と

2. 出血傾向の成因の把握

《術中》3. 補充療法十必要最小限の手術侵襲

《術後》4. 肝硬変自体の長期的専門的管理

以上の点を順に考察する。

\section{1 肝硬变および出血傾向の合併に気づくこと}

肝硬変は，病因のいかんを問わずすべての肝疾患の終 末像であり，慢性疾患である ${ }^{9)}$.したがってその患者は， 非外傷性敛出血を発症する相当以前加ら医療機関にか かっていることがほとんどである。しかしながら，非外 傷性脳出血を発症した時点では，意識障害があったり， または以前の医療機関との連絡なしに搬送されてきたり するので，脳出血を診る方の脳神経外科医にとっては既 往歴不詳の初診患者であることが少なくない.このため,
緊急時であればこそ一層, 本人・家族からの肝疾患や出 血傾向に関する既往歷聴取は重要である。また，神経学 的所見のみに目を奪われずに，肝硬変や出血傾向による 身体所見，すなわち，黄疸，〈も状血管拡張，手掌紅斑， 腹水, 脾腫, 出血斑などにも気づくことが肝要となる。 初䛦時・術前の感染症検査に HCV を含めることは当然 である．肝機能デー夕や凝固・線溶系デー夕も大事であ るが，これらには異常がみられないこともあるので，注 意が必要である ${ }^{9)}$. 頭部 CT 上の脳出血の部位としては 大脳皮質下が比較的多く，またその形状が不整形4)であ れば示唆的である。

\section{[2] 出血傾向の成因の把握}

もともと肝硬変患者は, 脳梗塞だけでなく, 非外傷性 脳出血も合併しにくいといわれている ${ }^{6)}$.すなわち, 肝硬 変が非外傷性脳出血の直接的原因となることは非常に少 ない1)16).しかし，いったん脳出血を起こすと，肝硬変に 特徵的な出血傾向または止血困難症のために，その治療 はむずかし(334)11). 肝硬変の出血傾向の主な成因として は以下の 3 点がある5)99.

(1) 血小板数の減少 (脾機能元進による)

(2) 凝固因子の産生低下（肝機能低下による）

(3) 線溶系の穴進〔肝機能低下による tissue plasminogen activator (tPA) の不活化遅延， $\alpha_{2}$ plasmin inhibitor $\left(\alpha_{2} \mathrm{PI}\right)$ の産生低下などによる]

症例によって，これらの中でどの要素が強いかの違いが あるため, 術前の凝固・線溶系デー夕で確認しておく必 要がある。

\section{3 補充療法十必要最小限の手術侵襲}

術前抢よび術中の血小板や凝固因子の補充療法なしに 
手術を行うことは危険である13)。たとえて言うならば， 抗血小板薬と抗凝固薬を内服している患者に，いきなり メスを入れてしまうようなものである。補充療法として は, 具体的には濃厚血小板や FFP の輸血が必要とな る15) が，実際には濃厚血小板は緊急時には間に合わない ことが多く, 合併症を覚悟のうえで院内採血による生血 輸血に踏み切らざるを得ないこともある。また，開頭手 術を長時間にわたって行っていると, 急速に血小板と凝 固因子の消費が進み，容易に補充療法の限界を迎えてし まうことになる。したがって，手術侵襲を必要最小限に 留める努力も重要である3)9).われわれの症例でも, 開頭 血腫除去術をせざるを得なかった 2 例が出血傾向による 合併症を生じたのに対して, 穿頭術で血腫除去を行い得 た 3 例はいずれも補充療法を併用し, 術後経過は良好で あった。

付加的事項として, 肝硬変患者の水頭症の手術時には, 出血傾向以外にも腹水の存在に注意しなければならな い. 水頭症に対して通常多用されている脳室一腹腔短絡術 は腹水を増量させてしまうので,脳室一心房短絡術などを 要することがある.

\section{4 肝硬变自体の長期的専門的管理}

抗生剤・麻酔薬などの種々の薬物投与を含む周術期管 理の影響により，肝機能が悪化することは多く，また， たとえ脳出血の急性期を乗り切ったとしても，もともと 肝硬変自体が予後不良なため, 長期経過は不良のことも 多い. 肝硬変の三大死因は肝不全, 消化管出血, 肝癌の 合併である ${ }^{9)}$ が, われわれの症例でも, 肝不全・食道静脈 瘤破裂などの肝硬変に直接起因する死亡例が 3 例あっ た。それゆえ，脳出血の発症当初から薬物の選択，栄養 管理, 肝硬変自体の合併症の精査と治療などについて, 肝臓病専門医との緊密な協力を行うことが重要であり， このことにより救命し得る症例が増加していくものと考 える。
本論文の要旨は第 53 回日本脳神経外科学会総会 (1994 年, 徳島) において発表した。

\section{文 献}

1) 荒木五郎: 肝硬変と脳出血. Clin Neurosci 6: 986-987, 1988

2）福田忠治, 秋元治郎, 陳 美利, 伊東 洋, 三輪哲郎, 蓮江正道：出血傾向に合併した頭蓋内血腫。治療の実際 と文献的考察。脳外 - 18：511-520，1990。

3) Furui T, Yamada A, Iwata K : Subdural hematoma as complication of hemostatic deficiency secondary to liver cirrhosis. Report of two cases. Neurol Med Chir (Tokyo) 29:588-591, 1989.

4）亀井徹正, 内山富士雄, 福山次郎：肝硬変患者にみられ た非外傷性頭蓋内出血. 5 症例の臨床的検討。神経内科 26 : 341-346, 1987.

5）金山正明：肝疾患と凝固異常. medicina 30：54-56, 1993.

6) Kane WC, Aronson SM : Cerebrovascular disease in an autopsy population. 4. Reduced frequency of stroke in patients with liver cirrhosis. Trans Am Neurol Assoc $96: 259-260,1971$.

7）金子満雄, 古場群己，保坂泰昭：肝硬変症に合併したと 思われる脸内血腫の 2 例 (抄録)。臨床神経 $18: 283$, 1978.

8) McCormick WF, Rosenfield DB : Massive brain hemorrhage: A review of 144 cases and an examination of their causes. Stroke 4:946-954, 1973.

9）水户廸郎，谷川久一：肝硬変のマネジメント．東京，医 学書院, 1993.

10）望月昭英，目黒琴生，成島 浄，庄司進一：肝硬変症に 合併した非外傷性後頭蓋窩硬膜下血腫. 神経内科 41 ： 464-468, 1994.

11）永井 肇，若林繁夫，高木卓爾：肝機能障害を伴った脳 室内出血の 1 例. 脳外 $7: 1133-1138,1979$.

12) Niizuma H, Suzuki J, Yonemitsu T, Otsuki T : Spontaneous intracerebral hemorrhage and liver dysfunc. tion. Stroke 19:852-856, 1988.

13）奥山正樹，上林純一：出血性患者の手術の実際．内科 72:1083-1086, 1993.

14）佐藤光夫，遠藤雄司，高萩周作，佐々木達也，児玉南海 雄：出血傾向を伴う慢性硬膜下血腫. 11 手術例の検討。 脳外 $23: 49-54,1995$.

15）田野崎隆二，半田 誠：血小板輸血および血漿製剤の適 応と使用の実際。内科 72:1087-1093，1993.

16）渡辺禮次郎，中林治夫，柳沢 徹：肝硬変と脳内出血. Clin Neurosci 8 :282-284, 1989. 


\section{肝硬変を伴つた非外傷性脳出血}

斉藤 厚志 成島 净 松村 明 目黒 琴生
能勢 忠男

肝硬变を伴つた非外傷性脑出血 9 症例について臨床的に検討した。男性が 7 例と多く, 肝硬变の原 因はC型肝炎ウイルスが 4 例と多かつた. 脳出血の部位は, 大脳皮質下出血が 4 例で最も多がった。 術前の血小板数は, 全例で低下しており, PT·APTT を術前に測定できた 6 例中, PT 延長を2 例に認めた. 開頭血腫除去術が 2 例に行われたが, 出血傾向による合併症を生じた. 穿頭血腫ドレナー ジ術は3例行われ, いずれも補充療法を併用し, 術後経過は良好であつた. 長期経過は, 肝不全, 食 道静脈瘤破裂などの肝硬变に直接起因する死亡例が 3 例あり, 不良のものが多かつた。独歩退院は, 皮質下出血に対する穿頭血腫ドレナージ術後の 2 例のみであつた. 